Original Research Paper

\title{
Peningkatan Hasil Belajar Peserta Didik Kelas XII SMKN 1 Sakra Pada Materi Pengolahan Hasil Hewani Melalui Penerapan Model Pembelajaran Berbasis Masalah
}

\author{
Rohatin Arpianingsih ${ }^{*}$ \\ ${ }^{1}$ Sekolah Menengah Kejuruan Negeri 1 Sakra, Indonesia.
}

*Corresponding Author:

Rohatin Arpianingsih,

Sekolah Menengah

Kejuruan Negeri 1 Sakra,

Indonesia;

Email:

rohatin.a@gmail.com

\begin{abstract}
Abstrak: Telah dilakukan penelitian tindakan kelas untuk mengetahui peningkatan hasil belajar siswa kelas XI SMKN 1 Sakra pada materi pengolahan hasil nabati dengan menggunakan model pembelajaran berbasis masalah pada semester genap tahun ajaran 2019/2020. Penelitian ini merupakan penelitian tindakan kelas yang dilaksanakan di SMKN 1 Sakra yang terdiri dari dua siklus. Tahapan PTK yang dilakukan adalah perencanaan, pelaksanaan tindakan, pengamatan dan refleksi. Data yang digunakan adalah hasil belajar siswa, hasil observasi guru dan hasil observasi siswa. Sabjek penelitian ini adalah ini adalah siswa kelas XII SMKN 1 Sakra yang berjumlah 40 orang. Hasil penelitian ini menunjukan bahwa model pembelajaran berbasis masalah dapat meningkatkan hasil belajar peserta didik pada materi pengolahan hasil nabati. Hal ini terlihat dari presentase ketuntasan sebesar $95 \%$ dengan nilai rata-rata ada siklus II adalah 75,00 .
\end{abstract}

Keywords: Hasil belajar; Peserta didik; Pengolahan hasil hewani; Model pembelajaran

\section{Pendahuluan}

Upaya maksimal untuk meningkatkan kualitas pendidikan dan pembelajaran berkelanjutan harus dilaksanakan dengan maksimal dan menyeluruh serta meliputi aspek pengetahuan, keterampilan, sikap. Tentu upaya integerasi aspek ini akan mendorong pengebangan sistem pendidikan yang tangguh agar mampu menghasilkan peserta didik yang siap bersaing diera global (Yubali, 2013, Ety Rochaety, 2006). Dalam pembelajaran agar mudah dimengerti oleh siswa, proses penalaran induktif dapat dilakukan pada awal pembelajaran dan kemudian dilanjutkan dengan proses penalaran deduktif untuk menguatkan pemahaman yang sudah dimiliki oleh siswa (Anas, 2014, Sudarsana, 2016).

Beberapa masalah ditemukan dalam pembelajaran di SMKN 1 Sakra salah satunya adalah hasil belajar dan motivasi belajar siswa sangat rendah, sebagian besar siswa belum memenuhi Kriteria Ketuntasan Minimal (KKM). Sebelumnya pernah dilakukan peneltian tindkaan kelas bahwa pembelajaran dengan model berbasis masalah dapat meningkatkan hasil belajar. Namun karena berbagai kendala waktu maka proses pembelajaran kembali ke system konvensional sebelumnya. Hal ini menyebabkan siswa terlihat bosan dengan metode mengajar yang diterapkan. Dimana peserta didik hanya menyerap informasi yang diberikan guru. Hal ini mengakibatkan siswa bermain dan tidak memperhatikan penjelasan guru. Sementara itu metode pembelajaran konvensional yang digunakan kurang efisien dimana siswa hanya siap menerima penjelasan dari guru kemudian mengerjakan contoh, sehingga siswa sulit dalam memahami materi yang diajarkan. Oleh sebab itu diperlukan upaya kembali untuk 
pengembangan kemampuan berpikir siswa agar mereka lebih aktif dan tertarik mengikuti pembelajaran.

Salah satu kelemahan proses pembelajaran yang dilaksanakan pada guru adalah kurang adanya usaha pengembangan kemampuan berpikir peserta didik (Sanjaya, 2007). Dalam proses pembelajaran guru lebih banyak mendorong agar siswa dapat menguasai sejumlah materi pelajaran. Model pembelajaran berbasis masalah merupakan suatu model pembelajaran aktif yang berdasarkan pada penggunaan masalah terstuktur sebagai rangsangan pembelajaran. Peran guru dalam model pembelajaran berbasis masalah adalah menyajikan masalah, mengajukan pertanyaan, dan memfasilitasi penyelidikan dan dialog (Rahman, 2018; Santyasa, 2007). Pembelajaran berbasis masalah melibatkan siswa untuk memecahkan masalah melalui tahap-tahap metode ilmiah sehingga siswa dapat mempelajari pengetahuan yang berhubungan dengan masalah tersebut dan sekaligus memiliki keterampilan untuk memecahkan masalah (Bandi, 2015). Berdasarkan uraian latar belakang di atas, maka rumusan masalah yang akan dikaji dalam penelitian ini adalah "Bagaimanakah peranan model berbasis masalah dapat meningkatkan hasil belajar siswa mata pelajaran peternakan kelas XII di SMKN 1 Sakra?" Adapun tujuan penelitian ini adalah untuk mengetahui peranan model berbasis masalah dalam pembelajaran sehingga dapat meningkatkan hasil belajar siswa kelas XII.

\section{Metode}

TPenelitian Tindakan Kelas yang dilakukan sekarang ini menggunakan model Kemmis dan Mc Taggart. Penelitian ini dilakukan pada siswa kelas XII SMKN 1 Sakra semester genap sebanyak 40 siswa. Penelitian ini dilakukan selama 2 siklus. Tiap putaran siklus dilakukan kegiatan-kegiatan perencanaan, pelaksanaan dan pengamatan, dan refleksi. Sebelum dilakukan PTK, peneliti lebih dahulu melakukan observasi terhadap pembelajaran yang berlangsung untuk menemukan masalah pembelajaran. Dari temuan hasil observasi awal kemudian dirancang atau direncanakan kegiatankegiatan perbaikan, mendesain perangkat pembelajaran, dan menyiapkan instrumen penelitian yang akan digunakan selama proses perbaikan pembelajaran. Pada saat penelitian berlangsung guru bertindak sebagai peneliti juga sebagai pengamat atau observer dan berkolaborasi dengan teman sejawat atau guru lain yang bertindak sebagai observer. Selama penelitian, observer mencatat fenomenafenomena yang terjadi dan kegiatan-kegiatan yang dilakukan oleh guru dan siswa dalam instrumen-instrumen pengamatan yang sudah disediakan oleh peneliti.

\section{Hasil dan Pembahasan}

Hasil penelitian kondisi pra-siklus hasil belajar peserta didik sangat rendah, minat dan motivasi peserta didik dalam mengikuti pembelajaran masih kurang, peserta didik belum berani mengajukan pertanyaan, susah menjawab soal, tidak berani mengemukakan pendapat dan kurang aktif. Hal tersebut dijadikan sebagai tolak ukur untuk meningkatkan minat dan motivasi hasil belajar peserta didik sehingga didapatkan proses dan hasil pembelajaran yang lebih baik khsusnya untuk meningkatkan hasil belajar peternakan pada materi pakan ternak rumansia dengan menggunakan model pembelajaran berbasis masalah.

Tabel 1. Nilai ulangan harian dan distribusi frekuensi ulangan harian kondisi awal

\begin{tabular}{llllll}
\hline Interval Nilai & Ulangan & Ulangan & No & Uraian & Ulangan
\end{tabular}




\begin{tabular}{lllllll}
\hline & harian 1 & harian 2 & & & harian 1 & harian 2 \\
$51-60$ & 15 & 12 & 1 & Nilai rendah & 50 & 55 \\
$61-70$ & 15 & 13 & 2 & Nilai tinggi & 78 & 80 \\
$71-80$ & 6 & 10 & 3 & Nilai rata-rata & 60 & 62 \\
$81-90$ & 4 & 5 & 4 & Rentang nilai & 28 & 25 \\
$90-100$ & 0 & 0 & & & & \\
\hline
\end{tabular}

Berdasarkan Tabel 1 bisa dilihat masih banyak siswa berada di bawah ketuntasan minimal. Sekita 30 orang dari 40 peserta didik masih belum tuntas. Pada prasiklus ulangan harian 1 terlihat bahwa nilai tertinggi 80 dan nilai terendah 50 dengan rata-rata 60 sedangkan data ulangan harian prasiklus II terlihat nilai tertingi adalah 82 dan nilai terendah 55 dengan ratarata nilai 62. Penelitian ini dilaksanakan dalam dua siklus. Siklus pertama terdiri dari masing-masing tiga kali pertemuan dan satu siklus terakhir terdiri dari satu kali pertemuan serta disetiap akhir siklus dilaksanakan tes.

\section{Hasil siklus I}

Tahapan pertaman dalah perencanaan. Dalam tahap perencanaan peneliti menyusun perangkat pembelajaran berupa rencana pelaksanaan pembelajaran (RPP) untuk siklus I, soal tes akhir siklus I, dan format pengamatan untuk siswa dan guru. Tahap selanjutnya adalah pelaksanaan tindakan. Pada tahap pelaksanaan tindakan dilakukan berdasarkan rencana pembelajaran yang telah disusun pada tahap perencanaan. Siklus I terdiri dari tiga kali pertemuan. Pertemuan pertama dilaksanakan dengan materi yang dibahas yaitu pakan ternak ruminansia. Di akhir pertemuan dilakukan tes akhir siklus I. Tahap ketiga adalah tahap observasi. Pada pertemuan pertama, guru belum optimal dalam memperhatikan peserta didik, hal ini disebabkan karna kurangnya control peserta didik dalam berdiskusi namun guru hanya memantau peserta didik dari depan kelas. Pada pertemuan kedua, proses pembelajaran belum menunjukkan adanya peninggkatan, melainkan proses diskusi masih didominasi oleh peserta didik yang pandai. Sedangkan pada pertemuan ketiga, terlihat adanya kontrolan guru terhadap peserta didik dalam berdiskusi, pada pertemuan ketiga peserta didik terlihat ada kerjasama namun belum terjadi secara optimal kepada semua peserta didik. Setelah tahapan observasi dilakukan maka dilanjutkan dengan tahapan refleksi. Berdasarkan analisis hasil pengamatan guru, hasil pengamatan siswa, dan hasilbelajar siswa maka dapat diketahui bahwa pada siklus I indikator keberhasilan belum tercapai sehingga perlu diadakan tindakan perbaikan pada siklus II agar hasil belajar siswa dapat ditingkatkan.

\section{Hasil Siklus II}

Tahap perencanaan siklus II. Berdasarkan siklus I maka dengan memperhatikan kelemahan dan kekurangan pada pelaksanaan siklusI dibuat perencanaan sebelum pelaksanaan tindakan siklus II. Selanjutnya Pelaksanaan tindakan. Pada tahap pelaksanaan tindakan dilakukan berdasarkan rencana pembelajaran yang disusun pada tahap perencanaan. Pelaksanaan siklus II sama dengan siklus I hanya saja yang membedakan materinya saja.

Hasil observasi terhadap penggunaan model pembelajaran berbasis masalah untuk meningkatkan hasil belajar peserta didik sangat membaik. Adapun aktifitas peneliti pada siklus ini sudah mulai membaik, dimana peneliti mengontrol aktivitas siswa juga sudah mulai terlihat, peneliti selalu berkeliling mengontrol dan memberikan pesertadidik semangat dalam menemukan masalah baru. Akan tetapi peneliti masih kurang tegas dalam mengambil tindakan dan proses pembelajaran. Hasil observasi terhadap guru presentase skor $95 \%$ artinya hasil hasil observasi sangat baik dibandingkan dengan siklus I. Hasil observasi 
terhadap peserta didik dapat dilihat dari kerjasama dalam mencari hal baru, keaktifan dalam berdiskusi serta keberanian peserta didik dalam memprsentasekan hal baru yang mereka temukan. Sedangkan hasil belajar peserta didik dapat dilihat berdasarkan keaktifan siswa dalam belajar karena dorongan guru yang selalu memberikan motivasi sehingga peserta didik semakin semangat dalam menemukan hal baru, hasil belajar peserta didik semakin meningkat dilihat dari evaluasi mandiri dengan nilai ratarata 76,50 dan presentase $87,50 \%$, hal ini menunjukkan bahwa meningkatnya hasil belajar peserta didik sudah tercapai sudah tercapai. Berdasarkan hasil refleksi pada siklus I dengan beberapa hal yang harus diperbaiki pada siklus II yang sudah mengalami peningkatan dalam meningkatkan hasil belajar dengan mengunakan model pembelajaran berbasis masalah pada pengolahan hasil nabati siswa kelas X SMKN 1 Sakra dapat meningkat dari siklus sebelumnya. Berdasarkan tabel 2 dapat direkap nilai tertinggi 85 , nilai terendah 65 dan nilai rata-rata 70 pada siklus 1 . Sedangkan nilai tertinggi pada siklus II 100, nilai terendah 68 , dan nilai rata-rata 75 . Hasil kami sesuai dengan hasil penelitian sebelumnya (Rahman, 2017; Arif, 2017)

Tabel 2. Hasil ulangan harian pada siklus I dan II

\begin{tabular}{lllllll}
\hline $\begin{array}{l}\text { Interval } \\
\text { Nilai }\end{array}$ & $\begin{array}{l}\text { Ulangan } \\
\text { harian } 1\end{array}$ & $\begin{array}{l}\text { Ulangan } \\
\text { harian 2 }\end{array}$ & No & Uraian & $\begin{array}{l}\text { Ulangan } \\
\text { harian 1 }\end{array}$ & $\begin{array}{l}\text { Ulangan } \\
\text { harian 2 }\end{array}$ \\
\hline $51-60$ & 12 & 5 & 1 & Nilai rendah & 65 & 68 \\
$61-70$ & 17 & 10 & 2 & Nilai tinggi & 85 & 100 \\
$71-80$ & 6 & 12 & 3 & Nilai rata-rata & 70 & 75 \\
$81-90$ & 4 & 7 & 4 & Rentang nilai & 20 & 22 \\
$90-100$ & 0 & 6 & & & & \\
\hline
\end{tabular}

\section{Kesimpulan}

Berdasarkan hasil dan pembahasan diatas maka dapat disimpulkan bahwa penggunaan model pembelajaran berbasis masalah dapat meningkatkan hasil belajar peserta didik kelas X SMKN 1 Sakra dalam materi pengolahan hasil nabati. Hal ini dapat dilihat dengan adanya peningkatan pada hasil tes yang dimulai dari tes akhir siklus I hingga akhir siklus II. Berdasarkan hasil penelitian guru dalam dua tahun terakhir ini maka disarankan menggunakan pembelajaran dengan model berbasis masalah karna dengan model tersebut peserta didik dapat mengembangkan cara belajar dengan aktif dan menemukan sendiri sehingga ingatan peserta didik kuat. Dalam pembelajaran guru guru dituntun untuk selalu aktif dalam proses kegiatan belajar mengajar sehingga dapat memberikan dorongan kepada peserta didik agar menjadi lebih semangat dalam mengikuti pembelajaran.

\section{Daftar Pustaka}

Anas, M., \& Pdi, M. (2014). Mengenal Metodologi Pembelajaran. Muhammad Anas.

Ani, Yubali. "Penilaian Autentik Dalam Kurikulum 2013." In Seminar Nasional Implementasi Kurikulum, Pp. 742-749. 2013.

Arif, A. S. (2017, October). Peningkatan Hasil Belajar Materi Elektrolisis Melalui Implementasi Model Pembelajaran Discovery Learning Di Kelas XII KI 1 SMK Negeri 1 Mojoanyar Semester 1 Tahun Pelajaran 2016/2017. In Seminar Nasional Pendidikan IPA (Vol. 1, No. 1, Pp. 628-640).

Asnita \& Gani, Erizal. (2020). Pengaruh Penggunaan Model Berbasis Masalah Terhadap Keterampilan Menulis Teks Eksplanasi Siswa Kelas VII SMP Negeri 20 Padang. Jurnal Pendidikan Bahasa Dan Sastra Indonesia, 9(1), 23-31. 
Kristin, Firosalia. (2016). Analisis Model Pembelajaran Berbasis Masalah Dalam Meningkatkan Hasil Belajar Siswa SD. Jurnal Pendidikan Dasar Perkhasa, 2(1),90- 98.

Laila, A. N. \& Budhi, W. (2017). Pengaruh Model Pembelajaran Berbasis Masalah Terhadap Prestasi Belajar Fisika. Jurnal Ilmiah Pendidikan Fisika, 4(2), 57-64.

Prasojo, Teguh. (2016). Peningkatan Aktivitas Dan Hasil Belajar Peternakan Dengan Metode Tutor Sebaya Pada Siswa Kelas $X$ IPA 7 Materi Trigonometri SMA Negeri 1 Kudus. Jurnal Peternakan Kreatif-Inivatif. 7(1), 91-98.

Rahman, A. (2017). Penerapan Model Pembelajaran Problem Based Learning Dalam Meningkatkan Hasil Belajar Peseerta Didik Pada Mata Pelajaran Gambar Konstruksi Bangunan Tentang Macam-Macam Irigasi Kelas Xii Bb Di Smk Negeri 2 Bogor Semester V Tahun Pelajaran 2015/2016. Syntax Literate; Jurnal Ilmiah Indonesia, 1(1), 1-15.

Rahman, T. (2018). Aplikasi Model-Model Pembelajaran Dalam Penelitian Tindakan Kelas. CV. Pilar Nusantara.

Sani, R. A. (2014). Pembelajaran Saintifik Untuk Implementasi Kurikulum 2013.

Santyasa, I. W. (2007). Model-Model Pembelajaran Inovatif. Universitas Pendidikan Ganesha. 